\title{
КОРЫ ВЫВЕТРИВАНИЯ И ПРИУРОЧЕННЫЕ К НИМ ПОЛЕЗНЫЕ ИСКОПАЕМЫЕ КАРЕЛО-КОЛЬСКОГО РЕГИОНА
}

\author{
В. Я. Евзеров \\ Геологический институт КНЦ РАН, г. Апатить
}

Поступила в редакцию 31 января 2019 г.

\begin{abstract}
Аннотация: в Карело-Кольском регионе обнаружены проявления и месторождения каолиновой и гидрослюдистой кор выветривания. Проявления каолина, как правило, характеризуются высоким содержанием красящих оксидов, особенно железа, и пригодны для изготовления иветной облииовочной плитки и дренажных труб. Более широкое применение после технологических испьтаний и экономической оценки, возможно, могут найти каолины проявления Аухтиярви в Карелии. В конце палеогена начале миоцена тектонический режим региона стабилизировался. Образовались педименты и приуроченная к ним кора выветривания гидрослюдистого типа. В ней установлено крупнейшее на Евразийском континенте месторождение вермикулита, разработка которого в настоящее время прекращена. Было бы иелесообразно вернуться к этому вопросу, и найти приемлемое решение для возобновления отработки месторождения, получения и рационального использования вспученного вермикулита из вермикулитового концентрата.
\end{abstract}

Ключевые слова: Карело-Кольский регион, коры выветривания, месторождения и проявления каолина и гидрослюд.

\section{WEATHERING CRUSTS AND ADJACENT MINERAL RESOURCES OF THE KARELIAN-KOLA REGION}

\begin{abstract}
: localities and deposits of kaoline and hydromica weathering crusts have been discovered in the Karelian-Kola region. Kaoline localities tend to have a high content of coloring oxides, particularly iron oxide, and can be used to produce color decorative stone and drainage pipes. Kaolines of the Aukhtijarvi deposit in Karelia can be widely used after technological tests and economic estimations. The regional tectonics became stable in the late Paleogene-early Miocene. Pediments and adjacent weathering crust of the hydromica type were formed. The Eurasia-biggest vermiculite deposit has been discovered here. Its processing has been stopped by now. It would be advisable to return to this issue, and find an acceptable solution for the resumption of mining the field, obtaining and rational use of expanded vermiculite from vermiculite concentrate.
\end{abstract}

Key words: Karelian-Kola region, weathering crusts, kaoline and hydromica deposits and localities.

\begin{abstract}
Введение
Сведения об эпохах выравнивания и связанным с ними образованием кор выветривания (КВ) на территории СССР проанализированы и систематизированы в работе $[1,2]$. В ней сделан предположительный вывод о возможно неоднократном развитии процессов выравнивания и корообразования в протерозое и палеозое. Значительно увереннее выделяются триасюрский, мел-палеогеновый, палеогеновый, олигоценмиоценовый, миоцен-плиоценовый и позднеплейстоцен-раннеплейстоценовый этапы выравнивания и корообразования.

Карело-Кольский регион расположен в пределах Балтийского кристаллического массива (щита), формирование складчатых структур которого закончи-
\end{abstract}

лось в протерозое. С этого времени щит испытывал лишь колебательные движения с общей тенденцией к поднятию и являлся преимущественно областью сноса материала, чем и объясняется его глубокая денудация. Тенденция к поднятию проявляется до сих пор. Поэтому вполне естественно, что в рассматриваемом регионе могли сохраниться только образования сравнительно молодых этапов выравнивания и корообразования. По современным представлениям в этой области встречаются остатки мезозойской и неогеновой КВ, о чем подробнее сказано ниже.

Остатки древних КВ сначала были обнаружены в западной части Кольского региона [3-5]. Затем доледниковые КВ были установлены практически по всему региону. Это обстоятельство позволило А. В. 
Сидоренко сделать вывод об ограниченности ледниковой экзарации и начать под своим руководством целенаправленное изучение упомянутых образований $[6,7]$. Итог этих комплексных исследований был подведен значительно позднее А. П. Афанасьевым [8], который выделил в пределах Балтийского щита КВ двух типов: каолиновой и более молодой гидрослюдистой. В восточной части Балтийского щита самым древним компонентом рыхлого покрова являются каолиновая и её магнезиальный аналог сунгулитовая КВ линейного типа [8]. Наиболее вероятно, что они представляют собой корни площадной КВ, некогда покрывавшей значительную часть пенепленизированной поверхности Балтийского щита [8]. Теплый и влажный климат, благоприятный для каолинового выветривания пород фундамента щита, имел место с конца триаса - начала юры до эоцена включительно [9-11]. Не имея материалов для надежного определения возраста, А. П. Афанасьев [8] счел целесообразным рассматривать останцы каолиновой КВ как мезозойско-палеогеновые образования.

К гидрослюдистой КВ А. П. Афанасьев [8] вслед за многими исследователями отнес глинисто-дресвянистый элювий преимущественно песчано-алевритового состава. Наиболее вероятное время формирования этого элювия по заключению А. П. Афанасьева миоцен-нижний плиоцен.

Цель данной статьи систематизировать имеющиеся сведения о КВ Карело-Кольского региона и оценить возможности практического применения продуктов выветривания.

\section{Каолиновая кора выветривания}

При образовании каолиновой КВ в материнских породах разрушались все неустойчивые и промежу- точные по устойчивости к агентам химического выветривания минералы, а образовывался, главным образом, каолинит или его магнезиальный аналог сунгулит. Не претерпевали изменений минералы устойчивые: кварц, титаномагнетит, ильменит, лейкоксен и ряд других.

В Карелии обнаружено два проявления каолинов [12] Аухтиярви и Проланваара (рис. 1 А). Первое из них представлено двумя залежами: Западной и Восточной, прослеженными бурением на 3000-5000 м. Западная залежь, вблизи поверхности достигает мощности 160 м. На глубину она выклинивается. Исходными породами, предположительно, являются катаклазированные и милонитизированные альбит-серицит-кварцевые сланцы, сложенные, в основном, кварцем (50-70 \%) и серицитом (30-40\%). Содержание каолинита в КВ составляет 24-26\%, кварца - 65 \%. По падению тела, количество каолинита несколько понижается. Разрез восточной залежи показан на рис. 1 Б. Исходными для её образования являлись альбитизированные кварциты. В продуктах выветривания содержание каолинита достигает 20-26\%.

Проявление Проланваара расположено на юге Карелии (рис. 1 А). Залежь прослежена на 200 м при ширине 6-10 м и представлена дресвяно-глинистой породой от кирпично-красного до светло-палевого цвета. Каолинит доминирует во фракции менее 0,001 мм, которая содержит большое количество железа, в связи с чем каолины не могут быть использованы в фарфоро-фаянсовой промышленности. В 30-е гг. ХХ в. проявление кустарно разрабатывалось для производства огнеупорного кирпича.

В Кольском регионе, как и в Карелии, специализированные поиски древних КВ не проводились.
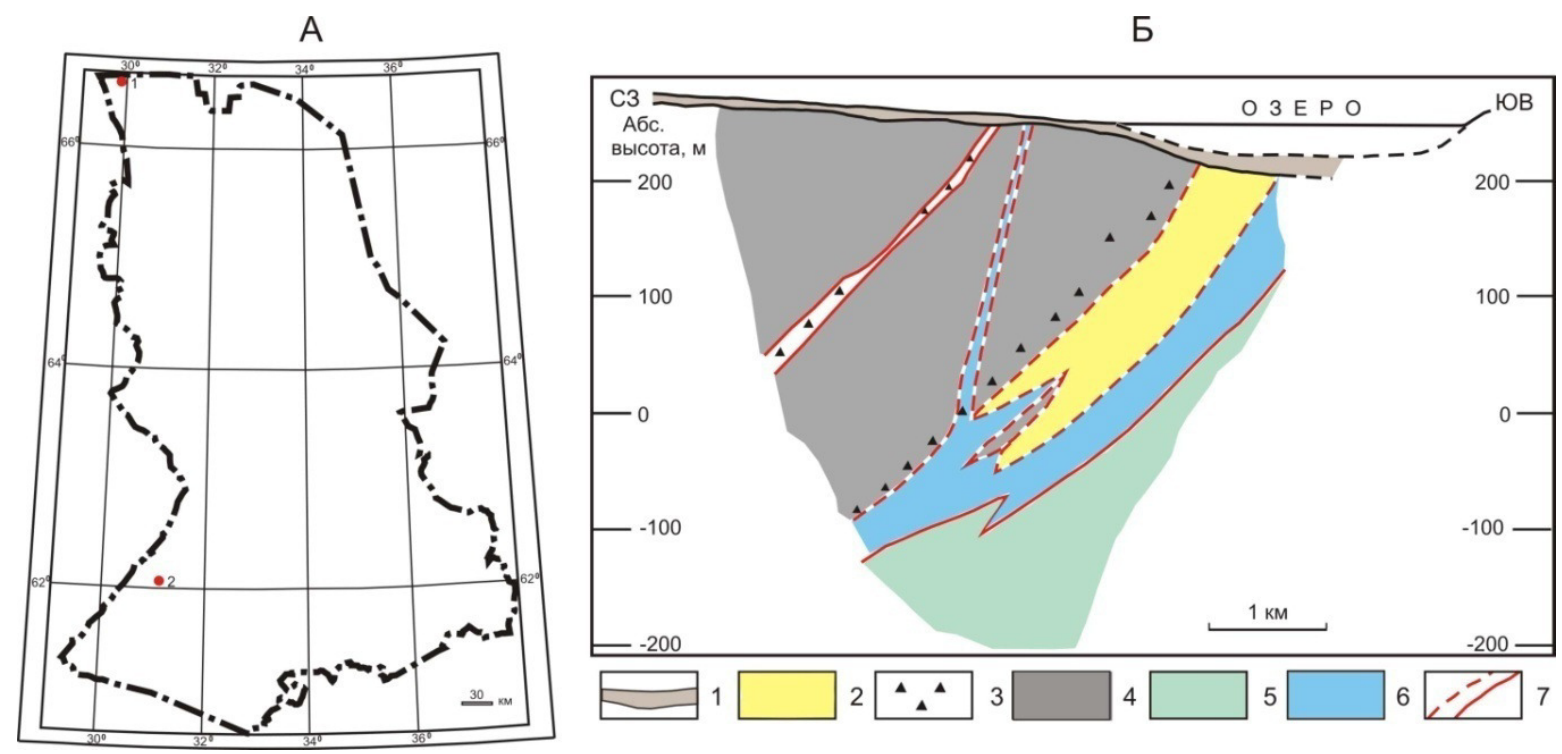

Puc. 1. Схема размещения проявлений каолинов Карелии (А) и разрез восточной залежи каолинов проявления Аухтиярви (приводится по [12]). А: проявления каолинов: 1 - Аухтиярви, 2 - Проланваара. Б: 1 - четвертичные отложения; 2 - каолиновая кора выветривания; 3 - зоны альбитизации; 4 - кварциты, серицит-кварцевые сланцы, биотит-амфиболовые и биотитовые сланцы с прослоями известняков и карбонат-кварцевых пород; 5 - гнейсы беломорской серии; 6 - бластокатаклазиты и бластомилониты; 7 - границы тектонических зон. 
Остатки этих геологических образований обнаруживались попутно при полевых исследованиях, проведении поисков и разведки других полезных ископаемых. Тем не менее, установлено достаточно много проявлений, в основном каолиновой и значительно реже сунгулитовой КВ. Большинство этих проявлений приведено на рис. 2. Попутно отметим, что на карте соседней Финляндии до 1998 г. было указано, по суще- ству, одно промышленное месторождение каолина Виртасалми - на юге страны. В период же с 1998 по 2005 гг. в северо-восточной части Финляндии, непосредственно граничащей с Кольским регионом и Карелией, в ходе целенаправленных поисков найдено более 20 проявлений каолина, последнее из которых - Виттаянка - находится в 5 км от финско-российской границы [13-17].

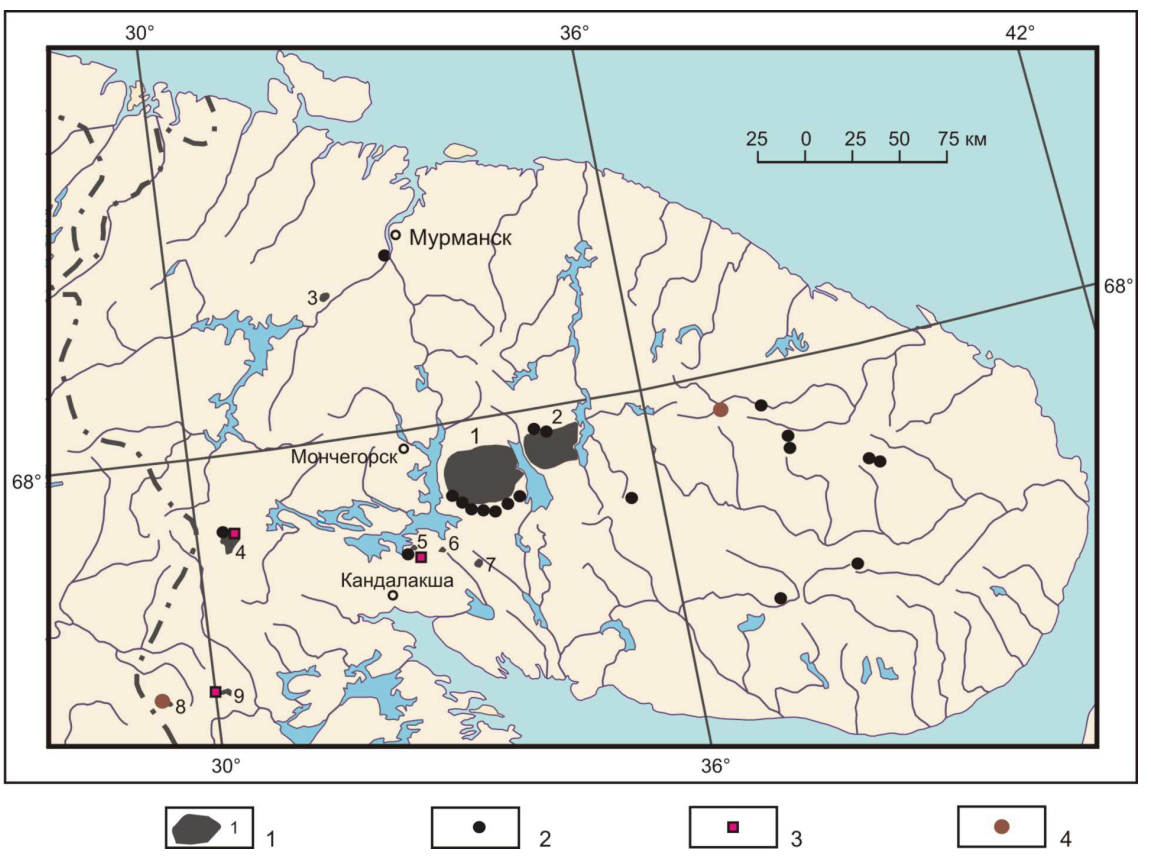

В Кольском регионе встречаются два типа залежей каолина: элювиальные, сохранившие реликтовые текстуры материнских пород, и делювиальные, образовавшиеся в результате переотложения материала из верхних частей элювиальных каолинов. И те и другие перекрыты четвертичными отложениями. Элювиальные каолины развиты в зонах, длина которых варьирует от 100 м до 2,5 км, а ширина от нескольких метров до первых сотен метров. Их мощность изменяется обычно от 2 до 30 м. По предварительным данным запасы каолина в отдельной залежи не превышают 5 миллионов тонн [18]. Наиболее крупные проявления обнаружены в северных предгорьях Ловозерских тундр и на Прихибинской равнине к югу от Хибинского горного массива. Мелкие проявления известны в районе Больших и Малых Кейв, сланцах серии имандра-варзуга, на восточном склоне горы Озерная варака и в других местах [8]. Они большей частью приурочены к зонам дизъюнктивных дислокаций. В окрестностях Ловозерских тундр, например, каолины локализованы в зоне разлома, протянувшегося субширотно вдоль контакта плутона нефелиновых сиенитов с вмещающими гнейсами, как показано на рис. 3.

Приведенный рисунок иллюстрирует типичный разрез наиболее крупной из известных залежей. В ней содержание частиц размером менее 0,05 мм составляет более $58 \%$; главными глинистыми минералами
Рис. 2. Схема распространения остатков каолиновой коры выветривания. Условные обозначения: 1 массивы щелочных и ультраосновных щелочных пород: 1 - Хибинский, 2 - Ловозерский, 3 - Себльявр, 4 - Ковдорский, 5 - Африкандский, 6 Озерная варака, 7 - Лесная варака, 8 - Салланлатва, 9 - Вуориярви; останцы каолиновой (2) и сунгулитовой (3) КВ; 4 - железная шляпа. Примечание: схема составлена по материалам, содержащимся в работах [4, $8,13,14]$. являются гидрослюды и каолинит. Концентрация этих минералов возрастает вверх по разрезу, и в верхней части залежи они становятся доминирующими. В песчаной фракции превалирует кварц (80-96\%), в небольших количествах присутствует гидробиотит. Из акцессорных минералов содержатся магнетит и ильменит (около 1,5\%).

К зонам разломов тяготеют залежи и на Прихибинской равнине. Они повсеместно представлены нижней гидрослюдисто-каолинитовой частью каолинитовой зоны КВ.

В рассматриваемом регионе наряду с каолиновой развита, как отмечалось, линейная сунгулитовая КВ. Она формировалась одновременно с каолиновой, но в специфической геохимической обстановке на породах ультраосновных-щелочных масссивов, таких как Ковдорский, Вуориярвинский и др. Залежи элювиальных сунгулитов достигают 2,5 км в длину, 800 м в ширину и имеют мощность до 100 м. Наиболее крупная из них обнаружена в Ковдорском массиве. Она показана на рис. 4. Переход от сунгулитизированных пород к неизмененным породам имеет место в тонкой зоне дезинтеграции. Преобладающим минералом залежей является сунгулит. Продукты сунгулитового выветривания, как и каолинитового, характеризуются высокими содержаниями оксида железа (около $10 \%$ ). Их технологические испытания не проводились. 
A

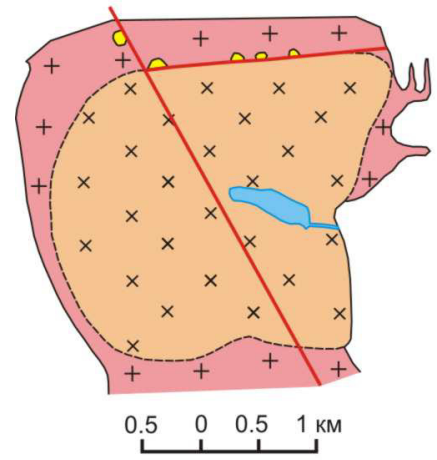

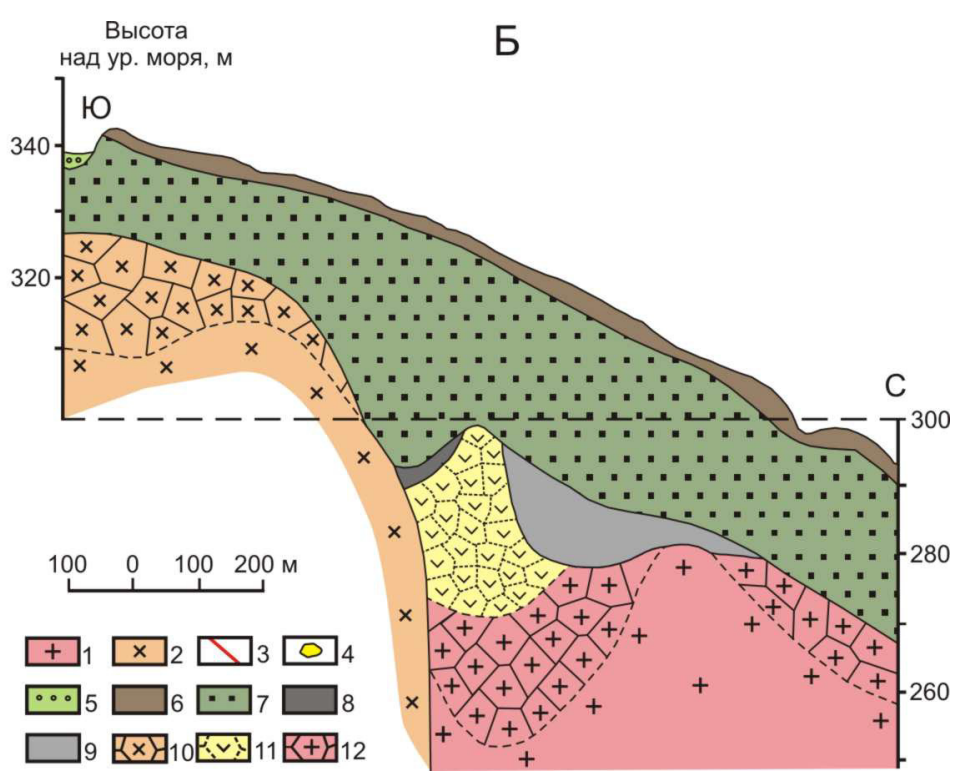

Рис. 3. Расположение залежей каолинов в северных предгорьях Ловозерских тундр (А) и типичный разрез одной из этих залежей (Б) (приводится по [13] с изменениями). А: 1 - гнейсы и гранито-гнейсы; 2 - нефелиновые сиениты; 3 - разломы; 4 залежи первичных каолинов. Б: 5 - современный аллювий; 6 - ледниковые отложения; 7 - четвертичные отложения различного генезиса (лопаритовая полигенетическая россыпь); 8 - делювиально-пролювиальные отложения неогена; 9 - неоген-четвертичный делювий каолиновой КВ; 10 - зона дезинтеграции нефелиновых сиенитов; 11 - гидрослюдисто-каолинитовая зона КВ; 12 - зона гидрослюдистая и дезинтеграции гнейсов и гранито-гнейсов.

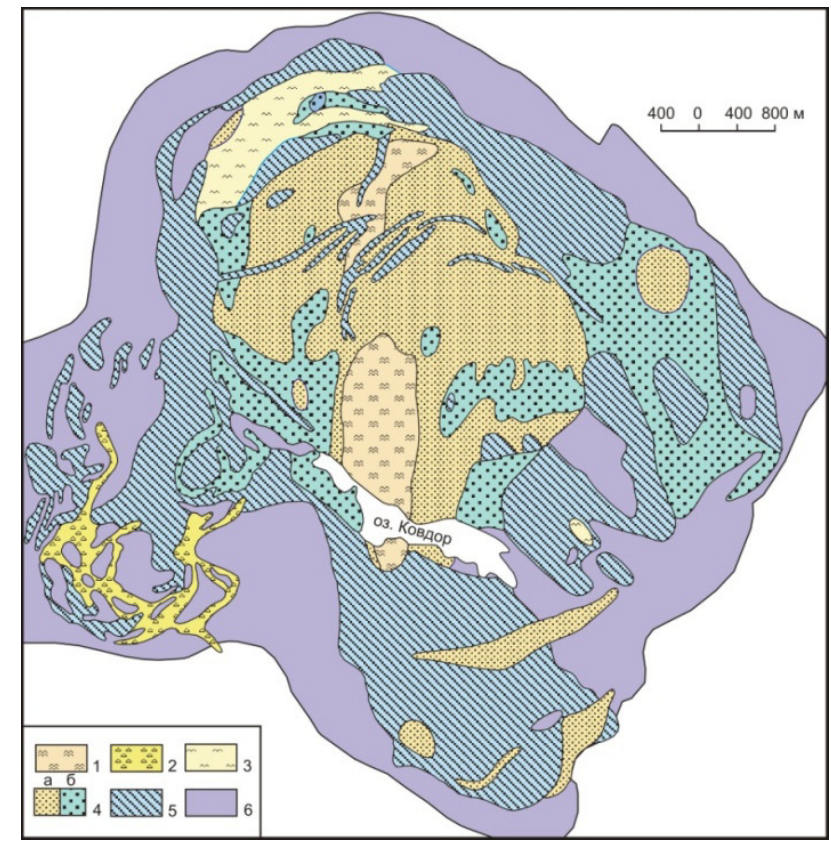

Pис. 4. Схема КВ Ковдорского массива ультраосновныхщелочных пород (приводится упрощенно по [8]). Условные обозначения: 1 - линейная гидрохлорит-сунгулитовая КВ ультраосновных пород; 2 - зона франколитизации; 3 - кальцитнонтронитовая и монтмориллонитовая зоны на монтичеллитовых и мелилитовых породах; 4 - гидрослюдистая КВ: вермикулитовый (а) и гидрофлогопитовый (б) горизонты; 5 - зона дезинтеграции пород различного состава; 6 - область отсутствия КВ.

Несомненный интерес представляют результаты исследований линейной КВ в пределах ФедоровоПанского расслоенного комплекса $[14,18]$. Здесь по данным комплексной аэрогеофизической съемки, выполненной в 1997-2001 гг., отчетливо выделяются две протяженные зоны электропроводности и пониженной намагниченности, субпараллельные простиранию магматической расслоенности. Кроме того, в пределах Западно-Панской и Восточно-Панской интрузии известны небольшие линейные участки повышенной электропроводности, и вдоль поперечных разломов. Эти зоны, показанные на рис. 5, вероятно, маркируют линейные коры выветривания. На южном склоне возвышенности Пешемпахк локальная аномалия электропроводности подтверждена наземной электроразведкой. Ширина зоны по данным А. Рокитянского, С. Мишукова, С. Сергеева достигает 100 м.

Зона разбурена. В западной части аномалии скважина П-209 вскрыла мощный чехол морены (18 м) и далее прошла 39 м по суглинистой коре выветривания вплоть до коренных габброноритов, заметно более измененных по сравнению с соседними участками. Восточная часть той же аномальной зоны, в 1400 м от западной, изучалась более подробно наземной электроразведкой и бурением. Судя по полученным материалам, общая ширина проводящей зоны достигает 500 м, составляя около 200 м в наиболее проводящей части. Разрез зоны трехслойный с проводящим промежуточным слоем, мощность которого в средней части зоны при удельном сопротивлении 200 Ом·м достигает 30-40 м. Результаты бурения по скважине П-211 показали, что верхнему слою с сопротивлением порядка тысяч Ом·м соответствует морена с высоким содержанием грубообломочного материала, среднему проводящему слою сопротивлением 200-300 Ом·м толща суглинистых образований, а опорному 


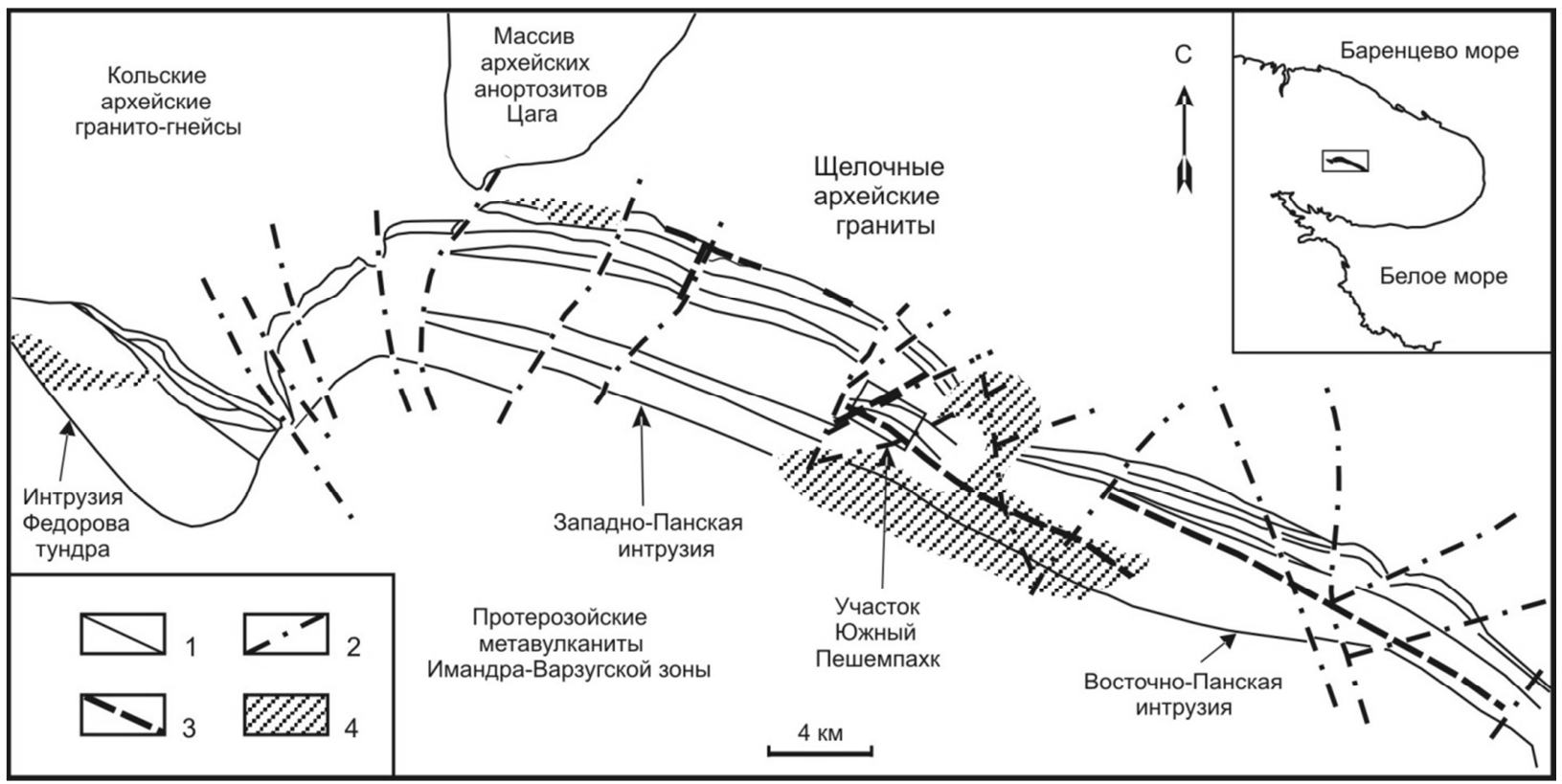

Puc. 5. Обзорная геологическая схема Федорово-Панского интрузивного расслоенного комплекса (ФПК) (приводится по [14]). Условные обозначения: 1 - разломы; 2 - геологические границы, в том числе магматической расслоенности; 3 - предполагаемые линейные КВ (по данным аэрогеофизики); 4 - области площадного развития четвертичных отложений в пределах комплекса.
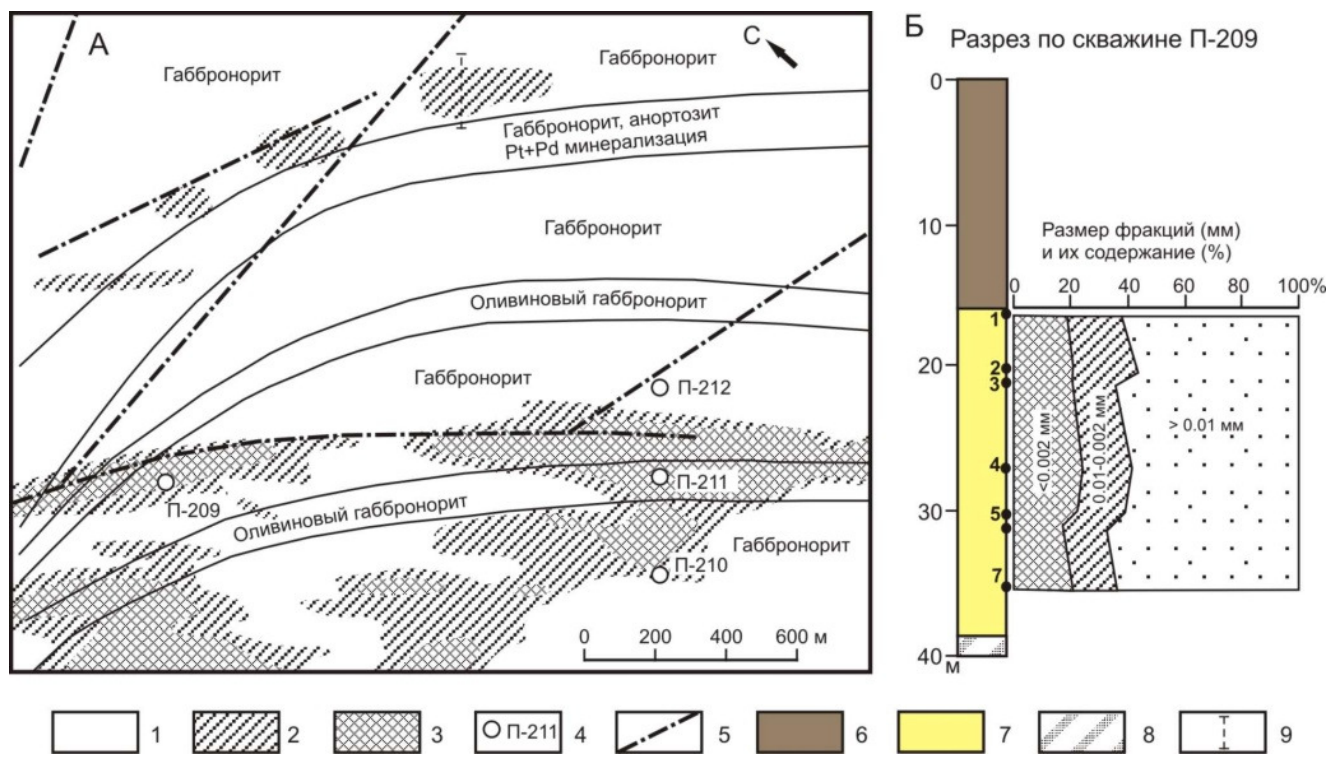

Puc. 6. Геолого-геофизическая схема участка Южный Пешемпахк (А) и разрез по скважине П-209 (Б) (приводится по [14]). Удельные сопротивления по ВП-СГ: 1 - более 7000 Ом ·м, 2 - 3500-7000 Омм, 3 - менее 3500 Ом·м; 4 - скважины по КВ; 5 разломы по данным магниторазведки и бурения; 6 - отложения морены; 7 - глинистая КВ; 8 - коренные габбронориты, измененные до амфибол-хлорит-клиноцоизитовых сланцев; 9 - положение разреза ВЭЗ-ВП. Примечание. Цифрами на разрезе указаны номера проб.

горизонту высокого сопротивления (десятки тысяч Ом·м) - коренные содержащие оливин габбронориты, интенсивно измененные вплоть до амфибол-хлоритклиноцоизитовых сланцев. Таким образом, проводящая зона протяженностью около 2 км и шириной 100 200 м может уверенно интерпретироваться как линейная кора выветривания измененных основных пород мощностью в десятки метров. Схема строения участка Южный Пешемпахк с результатами геолого-геофизических работ приведена на рисунке 6. Серии верти- кальных электрических зондирований вызванной поляризации (ВЭЗ-ВП), выполненные в 1000 м к северу от охарактеризованной полосы, пересекают одну из аномалий проводимости, трассирующих секущую разломную зону (рис. 6). Их интерпретация свидетельствует о наличии в разрезе рыхлого покрова глинистых пород мощностью от 2 до 15 м.

КВ в керне скважин представлена суглинком светло- или темно-серого цвета с реликтами измененных коренных пород, сохранившим текстурный 
рисунок исходной породы. Она сформировалась на габброноритах, измененных вплоть до хлоритамфиболовых сланцев. Содержание частиц размером менее 0,01 мм в выветрелом материале по обеим скважинам варьирует от 32 до $57 \%$. Пелитовые частицы представлены в основном хлоритом. В качестве примеси присутствуют иллит, амфибол и полевые шпаты. В образцах 1 и 2 из скважины П-209 появляется каолинит. Исследованные продукты выветривания по гранулярному составу и минеральному составу глинистых частиц аналогичны продуктам гидрохлоритовой зоны каолинитовой коры выветривания хлоритовых сланцев в районе станции Титан [8]. В указанном районе гидрохлоритовая зона вверх по разрезу сменяется каолинитовой зоной, содержащей около $70 \%$ частиц менее 0,01 мм и представленной в глинистой фракции почти нацело каолинитом. В нашем же случае начало перехода к каолинитовой зоне установлено только в разрезе по скважине П-209, которая расположена на 56 м ниже, чем скважина П-211. Соответственно, и КВ в окрестностях первой из упомянутых скважин менее денудирована. Данные по разрезу скважины П-209 позволяют предполагать, что образования каолинитовой зоны могли более полно сохраниться в других участках развития КВ [18].

На Прихибинской равнине близ оз. Имандра в зоне дробления альбит-хлоритовых, хлорит-тальковых и тальковых сланцев серии имандра-варзуга, содержащих местами пиритовую вкрапленность, наряду с каолиновыми глинами были обнаружены охристые продукты выветривания типа железной шляпы, представленной в основном гётитом $[7,8]$. Позднее железные шляпы были установлены на карбонатитовом штоке массива Салланлатва и в районе распространения кварц-двуслюдяных сланцев хребта Серповидного (Кейвы). Их положение показано на рис. 2. В первом пункте размеры железооксидных охр в плане составляют 0,5х0,7 км при мощности 3-32 м. Залежь по данным Б. В. Афанасьева (1995) (приводится по [19]) состоит из лимонита и гётита (41\%), барита $(23,8 \%)$, гематита, магнетита (4,6 \%), а также псиломелана, пиролюзита, гидрослюд, хлорита и карбонатов. Вторая залежь существенно меньше по размерам: в плане примерно 7х80 м. Её контакт с вмещающими кварц-двуслюдяными сланцами практически вертикален. Степень выветрелости сланцев по мере удаления от контакта уменьшается. Мощность гётитовой залежи и породы, по которым она формировалась, не установлены. Помимо основного минерала залежи гётита в ней диагностированы гематит, кварц, рутил, микроклин, альмандин, мусковит, роговая обманка, жедрит, циркон и барит [20]. Немногим более чем в 20 км к востоку-юго-востоку от железной шляпы (возвышенность Тяпш Манюк) канавой на кианитставролитовых сланцах вскрыт останец каолиновой КВ мощностью до 1 м. Он, по данным В. Ю. Калачёва и А. А. Котова, сложен песчано-глинистым материалом с дресвой кристаллических пород. Во фракции менее 0,01 мм рентгенометрически установлены в значительном количестве кварц и каолинит с примесью хлорита, иллита и полевого шпата.

Процессы, имевшие место на суше в мезозое, отразились в составе обломочного материала, сносимого с Балтийского щита в Южно-Баренцевоморскую впадину [21]. Анализ этого материала позволяет уточнить время формирования рассматриваемой КВ и свидетельствует о её образовании в пределах Балтийского щита в верхнем триасе-начале нижней юры [22]. Сделанное заключение согласуется с наличием на большей части территории бывшего СССР триас-нижнеюрского пенеплена с мощной КВ [23-25]. В течение нижней и средней юры верхние горизонты этой коры явились источником материала, поступавшего в Южно-Баренцевоморскую впадину. К началу верхней юры, очевидно, сохранились только корни упоминавшейся КВ. В верхней юре, начиная с волжского века, Балтийский щит становится одним из главных источников обломочного материала для осадков центральной части Восточно-Европейской платформы [26]. Остается открытым вопрос о возможном возобновлении процесса корообразования на щите в позднем мелу вследствие отсутствия данных о составе осадков этого отрезка геологической истории. В палеогене сколько-нибудь мощная КВ не могла сформироваться, поскольку в этот период щит представлял собой низменную сушу и, соответственно, уровень грунтовых вод располагался вблизи поверхности. Таким образом, имеющиеся материалы с наибольшей вероятностью свидетельствуют о триасюрском возрасте залежей каолина Балтийского щита [23]. С такой трактовкой возраста первичных каолинов региона хорошо согласуются данные по осадочным породам мезозоя в южной Швеции, обобщенные в монографии А. П. Афанасьева [8].

\section{Гидрослюдистая кора выветривания}

В палеогене сколько-нибудь мощная КВ не могла сформироваться, поскольку в этот период щит представлял собой низменную сушу и, соответственно, уровень грунтовых вод располагался вблизи поверхности. Отложения палеогена в северо-восточной части Балтийского щита не обнаружены. Они установлены лишь в одном пункте Финской Лапландии, расположенном примерно на широте города Кандалакши в 50 км к западу от границы России [27]. Там на кристаллических породах залегает палеогеновая морская глина. Перекрыта она тремя горизонтами морен. Кроме того, в четвертичных отложениях Кольского региона и северной Финляндии встречаются реликты морских диатомей палеогена. Все это дает основание полагать, что в палеогене значительные площади северной части Балтийского щита покрывались морем.

Последующая история континентального развития Карело-Кольского региона, в частности, и всего Балтийского щита в целом запечатлена в неогеновых образованиях, представленных, главным образом, КВ гидрослюдистого типа. Последняя широко распространена в Кольском регионе и по заключению А. П. 
Афанасьева встречается в Карелии [8]. Однако конкретные материалы по Карелии в упомянутой работе не приведены. Не удалось их обнаружить и автору данной статьи, что, конечно же, не свидетельствует об их отсутствии вообще.

В позднем олигоцене - неогене имело место значительное похолодание, усиливающееся во времени [28]. В неогене рассматриваемая территория достаточно длительное время находилась в полосе умеренного климата. Неоген отличался от палеогена высокой тектонической активностью [28, 29]. В конце палеогена - начале миоцена произошло поднятие Кольского региона, после чего в его пределах начали накапливаться континентальные осадки. Об этом свидетельствуют находки только пресноводных неогеновых диатомей в четвертичных отложениях региона. Признаки стабилизации тектонического режима проявились в образовании педиментов и в появлении КВ гидрослюдистого типа, которая в отличие от каолиновой имеет более тесную связь с современным рельефом. Эта КВ развита на невысоких водораздельных пространствах, пологих склонах возвышенностей и предгорных равнинах в пределах всего Балтийского щита. Она залегает как на мезозойской, так и на более молодой неогеновой поверхности и сохранилась в виде останцов, площадь которых достигает десятков (до сотен) квадратных километров; мощность изменяется от 5 до 20 м, увеличиваясь на породах ультраосновных-щелочных массивов до 50 м и более. Останцы неогеновой коры повсеместно представлены песчанодресвянистыми, реже глинисто-песчаными продукта- ми, среди которых имеются округлые участки менее измененных или измененных только с периферии исходных пород. Они обнаружены на породах почти всех щелочно-ультраосновных и щелочных массивов Кольского полуострова. По составу эти участки обычно не отличаются от материнских пород.

Останцы неогеновой КВ щелочных пород Ловозерского плутона широко развиты на северных склонах образованного интрузивным массивом горного сооружения (Ловозерских тундр). Площадь их распространения точно не установлена; мощность в отдельных скважинах достигает 17 м. Зона выветривания пород представлена глинисто-дресвяным материалом. Глинистые продукты выветривания - метагаллуазит, гидраргиллит и гетит - присутствуют в небольших количествах. Содержание их возрастает вверх по разрезу [30].

При образовании гидрослюдистой коры выветривания протекали процессы механического разрушения пород, физико-химического дробления минералов, приводящего к генерированию алевритовых частиц, и химического преобразования исходного материала [8]. Характерными минералами являются гидрослюды и вермикулит, возникшие в результате изменения главным образом триоктаэдрических слюд, а также галлуазит, каолинит и сунгулит, синтезированные в небольших количествах из продуктов выщелачивания и гидролиза. В неогене при выветривании частично разрушались амфиболы, пироксены и полевые шпаты.

В распределении остатков гидрослюдистой КВ наблюдается определенная закономерность (рис. 7).

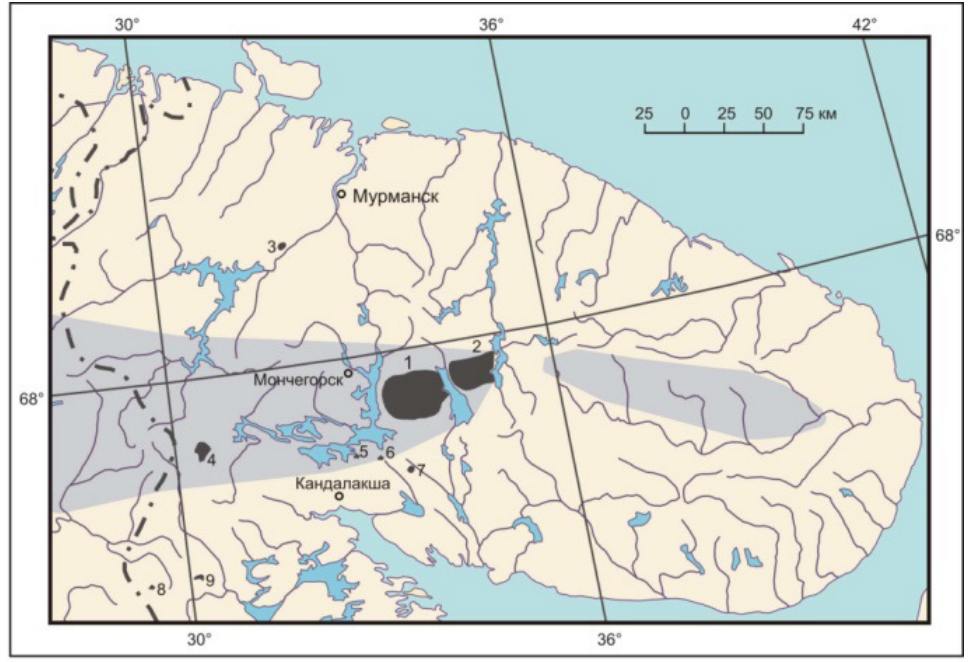

$\mathrm{O}_{1}$
Рис. 7. Схема распространения остатков гидрослюдистой КВ. Условные обозначения: 1 - массивы щелочных и ультраосновных щелочных пород: 1 - Хибинский, 2 - Ловозерский, 3 Себльявр, 4 - Ковдорский, 5 - Африкандский, 6 - Озерная варака, 7 - Лесная варака, 8 - Салланлатва, 9 - Вуориярви; 2 - область наибольшего распространения останцов гидрослюдистой КВ. Примечание: схема составлена по материалам, содержащимся в работах [31-34].
Останцы, занимающие значительные площади и имеющие большую мощность, сконцентрированы в пределах субширотной полосы, ось которой на западе близка к $68^{\circ}$ с.ш.; в Мурманской области по мере продвижения в восточном направлении всё более отклоняется к югу. Ширина полосы, достигающая у границы Финляндии с Норвегией 160 км, постепенно уменьшается в восточном направлении. В районе Ло- возерских тундр и среднего течения р. Поной она составляет около 60 км. Севернее полосы останцы гидрослюдистой КВ встречают крайне редко; южнее останцы обнаруживаются несколько чаще, чем на севере региона, но тоже редки и характеризуются малыми мощностями. Расположение полосы в общих чертах совпадает с зоной миграции ледоразделов четвертичных ледниковых покровов - зоной наименьшего 
экзарационного воздействия ледников на подстилающие породы [35]. Гидрослюдистая КВ частично размыта; в ряде пунктов региона на склонах холмов и в предгорьях обнаружены делювиальные и делювиально-пролювиальные отложения, сходные с нею по составу.

К КВ гидрослюдистого типа приурочены месторождения гидрофлогопита и вермикулита. Их распространение в пределах Ковдорского массива показано на рис. 4. На породах Вуориярвинского массива обнаружено только месторождение гидрофлогопита. Формирование месторождений обусловлено двумя процессами: щелочным метасоматозом, который привел к интенсивному ослюденению оливинитов, и последующему выветриванию флогопит содержащих пород [8]. В итоге в Ковдорском массиве возникла мощная кора выветривания, в которой отчетливо выделяются три зоны (снизу вверх): дезинтеграции исходных пород, гидрофлогопитовая и вермикулитовая. Они представлены на рис. 8.

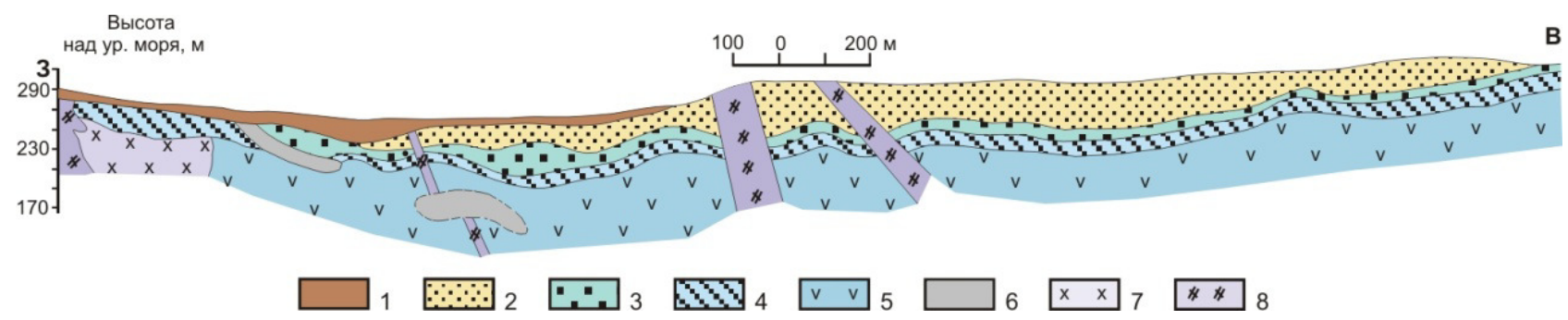

Puc. 8. Геологический разрез гидрослюдистой КВ Ковдорского массива на ультраосновных породах (приводится по [8] с небольшими изменениями). Условные обозначения: 1 - четвертичные отложения; 2 - вермикулитовый горизонт; 3 - гидрофлогопитовый горизонт; 4 - зона дезинтеграции; 5 - ультраосновные породы; 6 - карбонатиты; 7 - турьяиты; 8 - ийолит-мельтейгиты; 9 - дайки щелочных пород.

Ковдорское месторождение вермикулита крупнейшее на Евразийском континенте. Балансовые запасы вермикулита составляют по категориям $\mathrm{B}+\mathrm{C}_{1}$ около 21 млн т [36]. ООО «Ковдорслюда» ранее после переработки вермикулитовых руд получало только концентрат, выход которого составлял около 50 \%. Дальнейшая переработка концентрата осуществлялась за пределами региона. В настоящее время добыча вермикулита не ведется.

По представлениям А. П. Афанасьева $[31,32]$ гидрослюдистая КВ формировалась в умеренном климате на протяжении, вероятно миоцена - нижнего плиоцена, что отвечает миоцен - плиоценовому этапу выравнивания на Русской равнине. Новые данные по тектоническим деформациям Баренцевоморской континентальной окраины в кайнозое свидетельствуют в пользу существенной активизации поднятия не в плиоцене, а в конце миоцена [37], что позволяет ограничить время образования гидрослюдистой КВ миоценом.

В плиоцене тектонические движения вновь активизировались. Значительная часть шельфа северных морей была осушена, и речные долины врезались глубже современного уровня. По результатам бурения, обобщенным А. А. Никоновым [38], устьевые участки древних погребенных долин Кольского полуострова располагаются в основном на отметках минус 40-60 м. На месте Белого моря, вероятно, возник замкнутый водоем. Следствием поднятия явилось частичное переотложение гидрослюдистой КВ. На склонах возвышенностей и в пределах предгорных равнин сформировались сходные с нею по составу делювиальные и делювиально-пролювиальные отложения, а в депрессиях накапливались озерные осадки. Склоновые образования, как отмечалось, установлены в ряде пунктов региона. Озерные отложения до сих пор не обнаружены. Косвенным указанием на их существование в прошлом служит присутствие, иногда в довольно большом количестве, пресноводных неогеновых диатомей в четвертичных осадках.

\section{Области применения и возможность использования полезных ископаемых, приуроченных к корам выветривания}

Каолиновое сырье, связанное с триас-юрской КВ, представляет практический интерес, как для производства керамики, так и в качестве наполнителя или пигмента при изготовлении высококачественной бумаги. Элювиальные каолины Кольского региона и проявление Проланваара Карелии характеризуются высоким содержанием красящих оксидов, особенно железа, вследствие чего не могут быть использованы при производстве фарфора, фаянса и бумаги. Результаты технологических исследований показали, что эти каолины пригодны для изготовления цветной облицовочной плитки и дренажных труб [17]. Что касается проявления каолинов Аухтиярви в Карелии, то они, вероятно, могут найти применение и как пигмент в бумажной промышленности. Необходимы экономическая оценка и технологические испытания. Делювиальные каолины сформировались преимущественно в четвертичный период в результате переотложения элювиальных образований. Их залежи невелики по масштабам и содержат в своем составе значительное количество инородного материала. Коммерческий интерес они могут представить лишь в исключительных случаях. Следует отметить, что практически все проявления каолинов Карело-Кольского региона залегают под четвертичными отложениями различной мощности. Поэтому наиболее вероятным представляется их использование как побочного продукта при 
отработке более ценных месторождений, например, лопарита Ловозерской россыпи или платины Федорово-Панского интрузивного комплекса.

Большую ценность представляет Ковдорское месторождение вермикулита, эксплуатация которого, как отмечалось, прекращена. Вспученный вермикулит, получаемый при обжиге вермикулита-сырца обычно при температуре 800-900 C, весьма эффективен для получения на его основе теплозащитных, жаростойких, акустических и отделочных материалов. Подробно вопрос об областях и возможностях применения вспученного вермикулита рассмотрен в специальной работе [36].

\section{Перспективы обнаружения новых месторождений коры выветривания}

Новые месторождения каолинов, пригодные как для изготовления керамики, так и для использования в качестве наполнителя или пигмента в бумажной промышленности могут быть обнаружены в КарелоКольском регионе. Наибольшую ценность представляют каолины, не содержащие красящих оксидов. Судя по опыту финских геологов, это возможно сделать в пределах распространения метаосадочных пород относительно низкой степени метаморфизма посредством использования аэромагнитной съёмки и наземных геофизических работ, сопровождаемых бурением [16]. Отечественный и зарубежный опыт показывают, что эффективны наземные методы как электро-, так и гравиразведки. Причем, чем меньше в исходной породе темноцветных минералов, тем больше вероятность того, что продукты её выветривания будут пригодны для использования в бумажной промышленности. В случае обнаружения каолины могут представлять самостоятельный интерес.

Поиски новых месторождений в гидрослюдистой КВ вряд ли целесообразны вследствие наличия, как отмечалось, очень крупного Ковдорского месторождения вермикулита.

\section{Заключение}

В Карело-Кольском регионе обнаружены продукты выветривания коренных пород, образовавшиеся в доледниковую эпоху и практически повсеместно залегающие под четвертичными отложениями. Наиболее древними являются проявления каолина, сформировавшиеся в триас-юрское время. Они, очевидно, представляют собой остатки мощной КВ, приуроченной к триас-нижнеюрскому пенеплену, который был распространен на большей части территории бывшего СССР. В известных проявлениях Кольского региона и проявлении Проланваара Карелии каолины характеризуются высоким содержанием красящих оксидов, особенно железа, вследствие чего они пригодны только для изготовления цветной облицовочной плитки и дренажных труб. Остается открытым вопрос о применимости для фарфорово-фаянсовой промышленности и при производстве высококачественной бумаги каолинов проявления Аухтиярви Карелии. Высококаче- ственные каолины могут быть обнаружены при целенаправленном ведении поисков в пределах распространения метаосадочных пород относительно низкой степени метаморфизма.

В миоцене в регионе образовалась гидрослюдистая КВ. В конце палеогена начале миоцена произошло поднятие Кольского региона, и тектонический режим стабилизировался. Признаки стабилизации проявились в образовании педиментов и в появлении КВ гидрослюдистого типа, которая в отличие от каолиновой имеет более тесную связь с современным рельефом. В ней установлено крупнейшее на Евразийском континенте месторождение вермикулита, разработка которого в настоящее время, к сожалению, прекращена. Было бы целесообразно вернуться к этому вопросу, и найти приемлемое решение для возобновления отработки месторождения, получения и рационального использования вспученного вермикулита из вермикулитового концентрата.

\section{ЛИТЕРАТУРА}

1. Поверхности выравнивания и коры выветривания на территории СССР / Под ред. И. П. Герасимова и А. В. Сидоренко. - Издательство М.: «Недра», 1974. - 444 с.

2. Савко, А. Д. Коры выветривания в геологической истории Восточно-Европейской платформы / А. Д. Савко, А. Д. Додатко. - Воронеж: Изд-во ВГУ, 1991. - 232 с.

3. Rosberg, I. Studien ueber Talbildungen im finischen Lappland und dessen Umgebungen, I. Das Tal des Tulomjok. / I. Rosberg. - Fennia, XXIV, № 4, Helsingfors, 1908. - 38 p.

4. Гореикий, Г. И. Доледниковая кора выветривания на Кольском полуострове. / Г. И. Горецкий // Природа. - № 4. 1938. - C. 101-102.

5. Ферсман, А. Е. Полезные ископаемые Кольского полуострова. / А. Е. Ферсман // Тр. Комисс. По проблемам минер. сырья АН СССР, сер. региональная, 1941.- Вып. 1. - 345 с.

6. Сидоренко, А. В. О доледниковой коре выветривания Балтийского щита. / А. В. Сидоренко // ДАН СССР. - 1956. T.106. - № 1. - С. 114-117.

7. Сидоренко, А. В. Доледниковая кора выветривания Кольского полуострова. / А. В. Сидоренко. - М.-Л., Изд. АН CCCP, 1958. - $107 \mathrm{c}$.

8. Афанасьев, А. П. Фанерозойские коры выветривания Балтийского щита / А. П. Афанасьев. - Л.: Наука, 1977. - 244 с.

9. Синицын, В. М. Древние климаты Евразии. Ч. 1. Палеоген и неоген / В. М. Синицын. - Л.: Изд. ЛГУ, 1965. - 168 с.

10. Синицын, В. М. Древние климаты Евразии. Ч. 2. Мезозой / В. М. Синицын. - Л.: изд. ЛГУ, 1966. - 167 с.

11. Климат в эпохи крупных биосферных перестроек / Под ред: М. А. Семихатова, Н. М. Чумакова. - М.: Наука, Тр. ГИН РАН. - Вып. 550.- 2004. - 299 с.

12. Минерально-сырьевая база Республики Карелия. Кн. 2: Неметаллические полезные ископаемые. Подземные воды и лечебные грязи : монография / В. П. Михайлов [и др.] ; отв. ред. В. П, Михайлов, В. Н. Аминов. - Петрозаводск: Респ. тип. им. Анохина, 2006. -355 с.

13. Лихачев, A. С. Новая находка доледниковых каолиновых глин на Кольском полуострове/ А. С. Лихачев, А. П. Афанасьев // Советская геология. - 1969. - № 9. - С. 116-120.

14. Евзеров, В. Я. Перспективы обнаружения залежей каолинов в пределах Федорово-Панского расслоенного комплекса, центральная часть Кольского полуострова / В. Я. Евзеров, П. В. Припачкин, К. О. Дудкин // Вестник Воро- 
неж. гос. ун-та. Сер.: Геология. - 2006. - № 1. - С. 122-128. 15. Lintinen, $P$. The Vittajänkä kaolin deposit / P. Lintinen, T. Al-Ani // Geological Survey of Finland, GTK, Special paper 38 - 2005. - P. 4-47.

16. Lohva, J. Geophysical investigation of kaolin and ilmenite deposit in Finland. / J. Lohva, J. Lehtimäki // Aerogeophysics in Finland 1972-2004 - methods, systems and applications, GTK, Special paper 39. - 2005. - P. 147-154.

17. Лихачев, А. С. О возможных путях использования Ревдинского каолина и поисках подобных месторождений в центральной части Кольского полуострова / А. С. Лихачев // Вопросы литологии фанерозоя Кольского полуострова. - Л.: Наука, 1972.- С.78-81.

18. Евзеров, В. Я. Линейная кора выветривания ФедоровоПанского расслоенного комплекса в северо-восточной части Балтийского щита / В. Я. Евзеров, П. В. Припачкин, К. О. Дудкин // Доклады РАН. - Т. 412. - №6. - 2007. С. $780-782$.

19. Кравченко, С. М. Магматический и постмагматические этапы формирования Томторских (север Сибирской платформы) и Хибинских (северо-восток Балтийского щита) месторождений редких элементов / С. М. Кравченко, В. Я. Евзеров // Наука и технология в России. - 1998 (28). - № 5. - C. 14-19.

20. Морфология и первые данные по минералогии коры выветривания - «железной шляпы», Серповидный хребет, Кейвы, Кольский полуостров / В. В. Коган [и др.] // Материалы Научной сессии, посвящённой Дню российской науки и 55-летию Кольского отделения РМО. Геологический институт КНЦ РАН, Кольское отделение РМО, 8 февраля 2011 г. / Ред. Ю. Л. Войтеховский. - Апатиты, 2011. - С. 51-57.

21. Шельфовая плита Баренцева моря / Ред. И.С. Грамберг. - Тр. Северной Промышленной ассоциации морских геологических исследований «Севморгеология» и Всесоюзного научно-исследовательского института геологии и минеральных ресурсов мирового океана «ВНИИокеангеология». - Л.: Недра, 1988. - 263 с.

22. Евзеров, В. Я. Новые находки каолина на Кольском полуострове и вероятный возраст каолиновых месторождениий Фенноскандинавского щита / В. Я. Евзеров, В. В. Колька, В. О. Назаренко // Комплексная оценка месторождений нерудного минерального сырья. - С.-Петербург: 1993. -С. $129-132$.

23. Петров, В. П. Основы учения о корах выветривания / В. П. Петров. - М.: Недра, 1967. -343 с.

24. Горелов, С. К. Основные закономерности и этапы развития поверхностей выравнивания на территории СССР / С. К. Горелов // Поверхности выравнивания и коры выветривания на территории СССР. - М., 1974. - С. 318-366.

25. Михайлов, Б. М. Фациальные типы рудоносных кор выветривания

и их эволюция в истории Земли / Б. М. Михайлов // Кора выветривания и гипергенное рудообразование. - М.: Наука. 1977. - C. 22-32.

26. Хожаинов, Н. П. Источники сноса обломочного материала для палеозойских и мезозойских отложений Воронежской антеклизы / Н. П. Хожаинов // Литология и стратиграфия осадочного чехла Воронежской антеклизы. - Воронеж: Изд. ВГУ, 1974. - С. 3-11.

27. Hirvas, H. Tertiaarista savea Savukoskella seka havaintoja tertiaarisista mikrofossiileista / H. Hirvas, R. Tynni // Geologi. 1976. - Vol. 28. - № 3. - P. 33-40.

28. Синицын, В. М. Древние климаты Евразии. Ч. 1. Палеоген и неоген / В. М. Синицын. - Л.: Изд. ЛГУ, 1965. - 168 с. 29. Мещеряков, Ю. А. Структурная геоморфология равнинных стран. / Ю. А. Мещеряков. - М.: Наука, 1965. - 388 с.

30. Евзеров, В. Я. Россыпные месторождения - уникальные образования в рыхлом покрове Балтийского щита / В. Я. Евзеров // Литология и полезные ископаемые. - 2001. - № 2. - C. $126-133$.

31. Афанасьев, А. П. Минералогия доледниковой коры выветривания Кольского полуострова и приуроченных к ней месторождений вермикулита / А. П. Афанасьев. - Л.: Наука, 1966. $-170 \mathrm{c}$.

32. Афанасьев, А. П. Типы кор выветривания Балтийского щита, их вероятный возраст и направление поисков в них полезных ископаемых / А. П. Афанасьев // Вопросы литологии фанерозоя Кольского полуострова. - Л.: Наука, 1972. C. $46-71$.

33. Киселёв, И. И. О распространении коры выветривания в западной части Кольского полуострова и её палеогеографическое значение / И. И. Киселёв // Изв. Всесоюзн. геогр. общества. - 1975. - Т. 107. - Вып.4. - С. 324-330.

34. Kujansuu, R. On landslides in Finnish Lapland / R. Kujansuu // Geol. Surv. Fin. Bull. 256, 1972. - 22 p.

35. Евзеров, В. Я. Роль древних кор выветривания в формировании антропогеновых отложений и связанных с ними месторождений северо-восточной части Балтийского щита / В. Я. Евзеров // Литология и полезные ископаемые. - № 1. 1978. - C. $50-58$.

36. Крашенинников, О. Н. Перспективы использования вермикулита Ковдорского месторождения в Мурманской области [Электронный ресурс] / О. Н. Крашенинников, С. В. Бастрыгина // Север промышленный. - 2012. - № 3. - Режим доступа: http://helion-ltd.ru/use-vermiculite-kovdor-depos/ ГРНТИ 38.57 .31 (дата обращения: 31.01.2019).

37. Палеогеографические обстановки и тектонические деформации Баренцевоморской континентальной окраины в кайнозое / Э. В. Шипилов [и др.] // Доклады РАН. - Т.407. № 3. - 2006. - С. 378-383.

38. Никонов, А. А. О древнейших долинах северо-восточной части Балтийского щита / А. А. Никонов // ДАН СССР. 1967. - T. 177. - № 5. - C. 1155-1158.

\section{GI FRC KSC RAS, Apatity}

Yevzerov V. Ya., Doctor of Geological and Mineralogical

Sciences

E-mail: yevzerov@geoksc.apatity.ru

Tel.: +7 (81555) 62793 